\title{
ZASADY PRAWA OCHRONY DZIEDZICTWA KULTURY - PROPOZYCJA KATALOGU
}

I. Pośród wielu różnych norm społecznych wyróżnia się normy prawne, które zgodnie $\mathrm{z}$ określonymi regułami inferencyjnymi sa wyinterpretowywane $\mathrm{z}$ zawartych $\mathrm{w}$ akcie prawodawczym przepisów prawnych. Podstawowym pojęciem nauk prawnych jest więc pojęcie normy prawnej, która - będąc wypowiedzia dyrektywalna - wyznacza jej adresatowi w danych okolicznościach określony wzór zachowania. Norma prawna nie jest zdaniem w sensie logicznym i tym samym nie można jej przypisać wartości prawdy albo fałszu; nie jest opisem rzeczywistości. Pośród całego zespołu norm prawnych szczególne znaczenie mają normy będące zasadami prawa ${ }^{1}$.

We współczesnym prawoznawstwie przyjęło się, że zasadę prawa używa się w dwóch podstawowych znaczeniach - opisowym oraz dyrektywalnym²; dalej przyjmuję to drugie jej znaczenie. Choć zaznaczyć przy tym trzeba, że nie ma jednej powszechnie akceptowanej definicji zasad prawa, a wielość koncepcji ich dotyczących zasłużyła na obszerne studia ${ }^{3}$. Pomijam tu także spotykane w literaturze rozróżnienia zasad prawa, norm programowych, innych standardów itp. jako nieistotne dla celu artykułu4

Cechą nadajaca normie prawnej status zasady prawa jest - jak się przyjęło uważać - jej doniosłość dla systemu prawa. Lech Morawski podkreśla, że: „Zasady prawne zasługują na szczególną uwagę z dwóch następujących powodów. Po pierwsze, stały się one najważniejszym instrumentem aktywizmu sędziowskiego, przy pomocy którego sądy rozwijają prawo, i po drugie, stanowia one modelowy przykład stosowania argumentacyjnych metod uzasadniania decyzji sędziowskich" ". Zasadą prawa jest więc norma prawna

\footnotetext{
${ }^{1}$ Najważniejszymi pracami w polskiej literaturze prawniczej poświęconymi zasadom prawa, które łącznie całościowo przedstawiają to złożone i skomplikowane zagadnienie prawoznawstwa, sa: S. Wronkowska, M. Zieliński, Z. Ziembiński, Zasady prawa. Zagadnienia podstawowe, Warszawa 1974; G. Maroń, Zasady prawa. Pojmowanie i typologie a rola w wyktadni prawa $i$ orzecznictwie konstytucyjnym, Poznań 2011; M. Kordela, Zasady prawa. Studium teoretycznoprawne, Poznań 2012; S. Tkacz, O zintegrowanej koncepcji zasad prawa w polskim prawoznawstwie (Od dogmatyki do teorii prawa), Toruń 2014; a także: M. Korycka-Zirk, Teorie zasad prawa a zasada proporcjonalności, Warszawa 2012.

2 S. Wronkowska, w: eadem, Z. Ziembiński, Zarys teorii prawa, Poznań 2001, s. 186 i n.; zob. szerzej: eidem, Zasady prawa. Zagadnienia podstawowe, Warszawa 1974, passim.

${ }^{3}$ Zob. M. Kordela, op. cit., passim.

${ }^{4}$ Zob. np. L. Morawski, Podstawy filozofii prawa, Toruń 2014, s. 233 i n.

${ }^{5}$ Ibidem, s. 231.
} 
chroniąca ważne dobro, wyrażająca określone wartości, służąca realizacji określonych idei ${ }^{6}$.

Przyjmując za Sławomira Wronkowska, szczególna rola zasad prawa w systemie prawnym polega na tym, że: po pierwsze, wyznaczają one kierunki działań prawodawczych - wskazuja, jakie stany rzeczy prawodawca powinien osiagnąc poprzez tworzenie prawa oraz jakich wartości w procesie prawodawczym nie może naruszać, a także wskazują pewne sposoby ukształtowania określonych instytucji prawnych; po wtóre, ukierunkowuja proces wykładni prawa, co jest bardzo istotne, gdyż zasady prawa są równocześnie dyrektywami interpretacyjnymi; po trzecie, wskazują kierunki stosowania prawa, a w szczególności czynienia użytku z tzw. luzów decyzyjnych; w końcu po czwarte, ukierunkowują sposób czynienia użytku z różnych, przysługujących określonym podmiotom praw ${ }^{7}$.

Co równie ważne, zasady prawa mają często charakter dyrektyw optymalizacyjnych, co znaczy, że niektóre z nich wyznaczaja pewne ideały, cele, do których należy dążyć, stany, które winno się starać zrealizować w jak największym stopniu, biorąc pod uwagę możliwości faktyczne i prawne ${ }^{8} \mathrm{i}$ zarazem akceptując to, że sytuacji idealnej można nigdy nie osiągnąć. Jest to o tyle ważne, że o ile normy-reguły muszą być tworzone adekwatnie do faktycznych możliwości ich stosowania, to zasady prawa moga wyznaczać kierunki, cele i drogi prowadzące do stanu pożądanego, nawet wówczas, gdy wiemy, że wyznaczany w nich stan jest bardzo odległy od rzeczywistości.

II. Wśród najważniejszych typologii zasad prawa należy wyróżnić przede wszystkim: 1) zasady wprost sformułowane w tekście prawnym (zasady explicite); 2) zasady wyinterpretowywane z tekstu prawnego, choć wprost niewyrażone w tekście prawnym (zasady implicite); 3) zasady prawa niewyrażone w aktach prawodawczych, a stanowiące składnik kultury prawnej (zasady implicite drugiego stopnia).

Jak zauważa na ten temat Wronkowska: „Wiążący charakter jakiejś normy-zasady opierać się może na tym, że została ona wprost sformułowana w tekście prawnym (co jest przypadkiem stosunkowo rzadkim), czy też, że da się ona odtworzyć z tekstu prawnego na podstawie wielu przepisów, kształtujących jaką́s instytucję według zakładanego przez prawodawcę wzorca. Wiążący charakter zasady prawa może się też opierać na niespornej doktrynie prawnej, uznającej daną zasadę za obowiązująca (uzasadnienie pozytywne), przy jednoczesnym braku przepisów wykluczających obowiązywanie danej zasady w określonym systemie prawnym (uzasadnienie negatywne). Zasady prawa posiadające takie właśnie uzasadnienie ich obowiązywania są bezspornym składnikiem historycznie ukształtowanej kultury politycznej i prawnej danego społeczeństwa i mogą być ujmowane jako swoiste normy zwyczajowe"9.

${ }^{6} \mathrm{Na}$ temat idei i zasad konstytucyjnych zob. A. Pułło, Idee ogólne a zasady prawa konstytucyjnego, „Państwo i Prawo” 1995, z. 8.

${ }^{7}$ S. Wronkowska, w: eadem, Z. Ziembiński, op. cit., s. 188.

${ }^{8}$ L. Morawski, op. cit., s. 235.

${ }^{9}$ S. Wronkowska, w: eadem, Z. Ziembiński, op. cit., s. 187. 
Na podstawie innego kryterium podziału zasad prawa wyróżnia się: zasady uniwersalne, rozumiane jako zasady całego systemu prawa, oraz zasady partykularne, rozumiane jako zasady części systemu prawa. Uszczegółowiając ten podział, wyróżnić można: 1) zasady ogólne sytemu prawa, którymi są najczęściej zasady konstytucyjne; 2) zasady poszczególnych gałęzi prawa; a także 3) zasady konkretnego aktu prawodawczego. W tym podziale zasady prawa „stanowią niejako idee regulatywne systemu prawa, jego poszczególnych gałęzi, a nieraz konkretnych regulacji prawnych" ${ }^{10}$. Co więcej, to właśnie zasady prawa „spełniają szczególną rolę w konstrukcji systemu prawnego, gałęzi prawa czy instytucji prawnej i ich funkcjonowaniu"11. Zaprezentowany tu podział nie jest jednak w żadnym razie podziałem rozdzielnym, zasada ogólna bowiem może być równocześnie zasadą danej gałęzi prawa, w końcu jest też najczęściej zasadą wyrażoną w danym akcie prawodawczym, czyli zasadą tego aktu, a zarazem kształtującą daną instytucję prawną. Co więcej, niektóre z zasad partykularnych mają charakter międzygałęziowy. Natomiast tylko co do zasad konstytucyjnych warto tu zauważyć, że w przeważającej większości teksty współczesnych konstytucji są formułowane właśnie w języku zasad prawa ${ }^{12}$.

W końcu podział zasad prawa może dotyczyć ich pochodzenia, tj. wyróżniania: 1) zasad prawa krajowego; 2) zasad prawa europejskiego; 3) zasad prawa międzynarodowego. Przy czym ze względu na integrację tych porządków prawnych jedna i ta sama zasada może być - i bardzo często jest - równocześnie zasada prawa krajowego, prawa europejskiego i prawa międzynarodowego.

III. Prawo ochrony dziedzictwa kultury jest dziś uznawane za tzw. kompleksowa gałą́ prawa ${ }^{13}$. Jednym z kryteriów wydzielania gałęzi prawa jest posiadanie własnych zasad prawa ${ }^{14}$, które to kryterium jest spełnione wobec rozważań zawartych w tym i następnym punkcie niniejszego artykułu. Należy więc dalej przyjrzeć się katalogowi zasad prawa ochrony dziedzictwa kultury.

Zastrzec przy tym trzeba, że rozważając kwestię zasad prawa ochrony dziedzictwa kultury, można wyróżnić z jednej strony znaczną liczbę ogólnych zasad systemu prawa oraz zasad poszczególnych gałęzi prawa, które mają znaczenie dla prawa ochrony dziedzictwa kultury, z drugiej - zasady specyficzne dla tej tylko kompleksowej gałęzi prawa, które co prawda mogą być równocześnie ogólnymi zasadami prawa lub zasadami poszczególnych gałęzi prawa, niemniej jednak konkretyzują swą treść na gruncie prawa ochrony dziedzictwa kultury. Tak na przykład - zważywszy na fakt, że podstawowych narzędzi prawnych ochrony zabytków dostarcza prawo administracyjne, a realizuje się

${ }^{10}$ L. Morawski, op. cit., s. 231.

11 S. Wronkowska, w: eadem, Z. Ziembiński, op. cit., s. 187.

12 L. Morawski, op. cit., s. 231.

13 Zob. K. Zeidler, Prawo ochrony dziedzictwa kultury jako nowa gałaź prawa, w: idem (red.), Prawo ochrony zabytków, Warszawa-Gdańsk 2014, s. 23-33; zob. też: idem, Przestrzenie badawcze prawa ochrony dziedzictwa kultury, „Gdańskie Studia Prawnicze” 33, 2015; nt. kompleksowej gałęzi prawa zob. S. Wronkowska, w: eadem, Z. Ziembiński, op. cit., s. 194.

14 Zob. K. Zeidler, Prawo ochrony dziedzictwa kultury jako nowa gałaź..., s. 28-29. 
ono w postępowaniu administracyjnym - wszystkie zasady Kodeksu postępowania administracyjnego, jeśli to dotyczy zabytków, stają się zasadami prawa ochrony zabytków. Podobnie niektóre zasady prawa europejskiego, które dotyczą ochrony dziedzictwa europejskiego, sa zasadami prawa ochrony dziedzictwa kultury ${ }^{15}$, pośród nich w szczególności zasada pomocniczości. Tu także szczególnego znaczenia nabierają zasady ustrojowe, jak zasada decentralizacji oraz zasada dekoncentracji. Jednakże dalej uwaga została poświęcona tylko tej drugiej grupie zasad prawa, czyli zasad specyficznych dla prawa ochrony dziedzictwa kultury.

W pierwszej kolejności, wskazać należy zasady konstytucyjne. I tu odnajdujemy zasadę prawa wyinterpretowywana z art. 5 Konstytucji RP, który stanowi, że „Rzeczpospolita Polska strzeże niepodległości i nienaruszalności swojego terytorium, zapewnia wolności i prawa człowieka i obywatela oraz bezpieczeństwo obywateli, strzeże dziedzictwa narodowego oraz zapewnia ochronę środowiska, kierując się zasadą zrównoważonego rozwoju”. Pośród sześciu najważniejszych wartości konstytucyjnych, które winny być w pierwszej kolejności objęte ochroną przez państwo, odnajdujemy „strzeżenie dziedzictwa narodowego”. Przy czym zasada „strzeżenia dziedzictwa narodowego” wymaga pewnej korektury interpretacyjnej, jej językowa wykładnia prowadzi bowiem ad absurdum (literalnie nakazane jest strzeżenie dziedzictwa narodowego; niezależnie od definicji narodu, jaką przyjmiemy - politycznej, etnicznej itd. - to a contrario nie ma obowiązku strzeżenia dziedzictwa niebędącego dziedzictwem narodowym). Tym samym należy uznać, że zasada, którą określam mianem zasady ochrony dziedzictwa kultury, swą podstawę interpretacyjną znajduje w art. 5 Konstytucji, jednakże jej treść wymaga korekty w procesie wykładni prawa, przy uwzględnieniu treści innych jeszcze przepisów Konstytucji, a także szerszego ujęcia systemowego.

Przepis ten ma znaczenie systemowe w tym sensie, że jego znaczenie normatywne rozciaga się na cały system prawa, a bezpośrednim adresatem obowiązku w nim wyrażonego jest państwo w całości, a w konsekwencji wszystkie jego organy; choć oczywiście to zadanie realizowane jest przez wyspecjalizowaną administrację rządową (Ministra Kultury i Dziedzictwa Narodowego i podporządkowane mu Ministerstwo Kultury i Dziedzictwa Narodowego). Warto także podkreślić doniosłość tego przepisu ze względu na dyrektywę wykładni systemowej a rubrica.

Należy więc stwierdzić, że zasada ochrony dziedzictwa kultury jest z jednej strony zasadą konstytucyjną polskiego porządku prawnego, z drugiej zaś ma charakter tzw. metazasady praw ochrony dziedzictwa kultury; znaczy to, że przez pryzmat tej zasady należy interpretować nie tylko inne zasady prawa ochrony dziedzictwa kultury, ale wszystkie bez wyjątku przepisy prawa krajowego - zarówno te, które zalicza się do prawa ochrony dziedzictwa kultury, jak i pozostałe, klasyfikowane w ramach innych gałęzi prawa.

15 Por. Z. Brodecki (red.), Europa sędziów, Warszawa 2007. 
IV. Podejmując próbę stworzenia katalogu zasad prawa ochrony dziedzictwa kultury, wskazać należy co najmniej poniższe; choć trzeba zastrzec, że zestaw tu zaproponowany ma charakter otwarty i wyobrazić można sobie uzupełnienie poniższej propozycji o inne jeszcze zasady.

Zasada dostępu do zabytków jest to także zasada konstytucyjna, wyrażona w art. 6 ust. 1 i art. 73 Konstytucji. Przy czym pierwszy z tych przepisów nakłada obowiązek na organy państwa - stanowiąc, że Rzeczpospolita Polska stwarza warunki upowszechniania i równego dostępu do dóbr kultury, będącej źródłem tożsamości narodu polskiego, jego trwania i rozwoju; drugi ze wskazanych przypisów przyznaje prawo podmiotowe, stanowiąc, że każdemu zapewnia się - obok wolności twórczości artystycznej, badań naukowych oraz ogłaszania ich wyników, wolności nauczania - wolność korzystania z dóbr kultury. Przepis ten znalazł się w rozdz. II Konstytucji RP: Wolności, prawa i obowiązki człowieka i obywatela, w części poświęconej wolnościom i prawom ekonomicznym, socjalnym i kulturalnym.

Zasada społecznej użyteczności zabytków opiera się na tezie, że zabytki winny być współcześnie dobrze wykorzystywane, można rzec „społecznie użyteczne". Zasada ta wypływa z kategorii zabytku jako dobra wspólnego i łączy się bezpośrednio z zasadą dostępu do zabytków ${ }^{16}$.

Zasada dostępu do informacji pozostaje w immanentnym związku z zasadą dostępu do zabytków oraz zasadą społecznej użyteczności zabytków, a opiera się na regulacjach unijnych i krajowych dotyczących dostępu do informacji publicznej, a także przepisach tzw. dyrektywy reuse i ustawy ją implementującej - zwłaszcza w zakresie, w jakim dotyczy muzealiów, materiałów bibliotecznych i archiwaliów.

Zasada kontroli stanu zachowania zabytków łączy się z dobrze znanymi nauce administracji pojęciami kontroli, nadzoru, monitoringu. Aby skutecznie realizować cele określone jako ochrona zabytków lub opieka nad zabytkami, konieczne jest bieżące uzyskiwanie informacji o stanie zabytków, tak aby - zarówno środkami tzw. miękkimi, jak i przez działania władcze - wpływać na właścicieli i posiadaczy zabytków tak, aby ograniczyć negatywne dla zabytków skutki.

Zasada integralności zabytku jest zbliżona do zasady integralności utworu, dzieła w prawie autorskim; różni się jednak istotnie celem, nie chodzi bowiem tyle o ochronę praw autora utworu, ile o ochronę samego zabytku przez ingerencją w jego kształt i formę. Łączy się ona bezpośrednio z zaleceniami wypracowanymi na gruncie tzw. teorii konserwatorskiej. Jak zauważa Monika Drela: „W interesie publicznym leży również samo zachowanie oryginalnej postaci zabytkowego przedmiotu na przyszłość, nawet wtedy, gdy obcowanie z nim dane jest jedynie waskkiemu gronu osób"17. Pokazuje to kontradyktoryjność niektórych z wyróżnianych w artykule zasad - tu przynajmniej w pewnym zakresie zasady powyższej z zasadą społecznej użyteczności zabytków;

${ }^{16}$ Por. szerzej: K. Zeidler, Restytucja dóbr kultury ze stanowiska filozofii prawa. O trudnych przypadkach na granicy kultury i prawa, Warszawa 2011, s. 197-200.

${ }_{17}$ M. Drela, Wtasność zabytków, Warszawa 2006, s. 2. 
jednakże tylko w pewnym zakresie, społeczna użyteczność dóbr kultury nie sprowadza się bowiem jednie do możliwości korzystania z nich przez ich jak najszersze i najłatwiejsze udostępnianie odbiorcy.

Zasada zrównoważonego rozwoju jest jedną z podstawowych zasad prawa ochrony środowiska, będąc zarówno zasadą uniwersalną - a to dlatego, że została wyrażona wprost w art. 5 Konstytucji - jak i zasadą partykularną prawa ochrony środowiska. Okazuje się jednak, że na zasadzie a simili można ją skutecznie adaptować na grunt prawa ochrony dziedzictwa kultury ${ }^{18}$.

Zasada zarządzania dziedzictwem kultury łączy się ze zmianą podejścia do zagadnienia ochrony zabytków, gdzie już sama idea ochrony rozumianej klasycznie jako pozostawienie bez zmian, bez ingerencji, zostaje porzucona na rzecz tzw. zarządzania zmiana. Akceptuje się więc ingerencję w substancję zabytkowa, zmianę funkcji zabytku, jego wartości użytkowych, tak aby mógł on być współcześnie wykorzystany, a przez to także odpowiednio zachowany.

Zasada zmiany wartości użytkowej dziedzictwa kultury w czasie opiera się na fakcie, że funkcja zabytku, określana także przez jego wartość użytkowa, zmienia się w czasie. Aby skutecznie chronić zabytki, trzeba akceptować zmianę ich funkcji, aby mogły dziś - co prawda inaczej niż w przeszłości - być wykorzystywane, aby odrzucone i porzucone nie popadały w ruinę prowadzacą do ich całkowitego unicestwienia. Zabytek użytkowany to „zabytek żywy”, ale będzie to możliwe, gdy będzie się poszukiwało nowych przeznaczeń dla obiektów zabytkowych. Zasadę tę można uznać za uszczegółowienie zasady zarządzania dziedzictwem kultury.

Zasada finansowania przez posiadacza zabytku łączy prawo własności lub fakt posiadania zabytku z odpowiedzialnością za finansowanie działań przy zabytkach. Pozostaje ona w relacji do zasady niżej wskazanej, czyli zasady finansowania ze środków publicznych - gdzie ważne jest odnalezienie odpowiednich relacji i proporcji między realizacją obu tych zasad. Należy jednak zważyć na to, że skoro uznajemy zabytki za dobro wspólne, którego zachowanie leży w interesie wspólnotowym, a nie tylko indywidualnym (właściciela lub posiadacza), a w efekcie tego założenia władza konserwatorska ingeruje w sferę wolności działania właściciela lub posiadacza - to winno to być rekompensowane $\mathrm{w}$ ten sposób, że realizacja szczególnych, dodatkowych obowiązków wobec zabytków winna uzyskiwać wsparcie ze strony dysponentów środków publicznych. Ważne jest więc właściwe ułożenie relacji tych zasad.

Zasada finansowania ze środków publicznych, dotycząca w szczególności finansowania opieki nad zabytkami, pozostaje w immanentnym związku z zasada poprzednia, tj. zasada finansowania przez posiadaczy zabytku, w tym sensie, że zasady te są kontradyktoryjne, a obowiązujące prawo wprowadza rozwiąania, które przyznaja jednej albo drugiej pierwszeństwo. Niemniej jednak warto, żeby jedna z nich uznana była za lex generalis, druga - za lex

${ }^{18}$ Zob. K. Zalasińska, T. Bąkowski, Paradygmat zrównoważonego rozwoju w prawnej ochronie nieruchomości zabytkowych - próba adaptacji, w: Wokót problematyki prawnej zabytków $i$ dziet sztuki, t. 3: Prawna ochrona dziedzictwa kulturowego, red. W. Szafrański, K. Zalasińska, Poznań 2009. 
specialis, tak aby nie było konieczne każdorazowe ważenie zasad, a jedynie (po spełnieniu przewidzianych przez prawo przesłanek) stosowanie regulacji szczególnej, będącej realizacją zasady kontradyktoryjnej.

Zasada ochrony własności jest o tyle ważna w prawie ochrony dziedzictwa kultury, że napotyka swe „uszczegółowienie zawężające” wynikające z metazasady ochrony dziedzictwa kultury, a to ze względu na możliwość ingerencji w prawa właściciela w imię dobra wspólnego, jakim jest ochrona poszczególnych składników dziedzictwa kultury, w pierwszej kolejności zabytków. Tym samym prawo ochrony dziedzictwa kultury wprowadza istotną ingerencję $\mathrm{w}$ zasadę ochrony własności. Niemniej jednak zasada ochrony własności jest bardzo ważna w świetle podziałów własnościowych zabytków, a przede wszystkich dlatego, że to właśnie właściciel najczęściej może - jeśli chce - zapewnić zabytkowi, stanowiącemu przedmiot jego własności, najskuteczniejszą ochronę (nie w sensie prawnym, ale faktycznym). Tym samym zasada systemowa, która jest zasada ochrony własności, ma istotne znaczenie dla prawa ochrony dziedzictwa kultury.

Zasada proporcjonalności jest ważną zasadą o charakterze proceduralnym; pozwala na rozstrzyganie sporu pomiędzy dobrem wspólnym (na którego straży winny stać organy ochrony zabytków) a interesem indywidualnym (najczęściej właściciela zabytku), które to dobra w konkretnych stanach faktycznych często pozostają ze sobą w kolizji. Zasada proporcjonalności jest więc niezwykle ważna w przypadku konfliktu zasad prawnych, gdyż to ona pozwala dynamicznie rozstrzygać w konkretnych stanach faktycznych o pierwszeństwie/wyższości jednej zasady przed/nad inna; w przypadku konfliktu zasad bowiem „są stosuje zasadę bardziej w danej sytuacji relewantna, co nie oznacza, że druga zasada traci moc obowiązująca, ani też nie wyklucza, że w innej sytuacji porządek preferencji może być inny. Jeśli jest to możliwe, sąd powinien zastosować obie zasady biorąc pod uwagę zasadę proporcjonalności, a więc uwzględniając doniosłość każdej z zasad"19. Rozstrzygając konflikty zasad, a dokładnie: wyrażanych przez nie wartości, należy kierować się zasadą proporcjonalności i uwzględniać: celowość, konieczność oraz proporcjonalność sensu stricto.

Zasada bezpieczeństwa (pewności) obrotu dobrami kultury w różnych państwach jest urzeczywistniana w różnym stopniu ingerencji prawodawcy w wolność rynkową ze względu na przedmiot obrotu, jakim są dzieła sztuki i zabytki ${ }^{20}$.

Z poprzednią zasada wprost związana jest zasada kontroli przemieszczania dóbr kultury. Ze swej natury dotyczy ona tylko zabytków ruchomych. Zastapiła ona wcześniej obowiązującą zasadę zakazu wywozu zabytków za granicę i jest rozwiązaniem pośrednim pomiędzy taką właśnie reglamentacją a zasadą wolności wywozu zabytków za granicę.

V. Na koniec należy zastrzec, że nie można w warstwie rozważań o zasadach prawa ochrony dziedzictwa kultury statycznie rozgraniczyć ochrony zabytków nieruchomych i ruchomych, a większość z przedstawionych tu zasad

${ }^{19}$ L. Morawski, op. cit., s. 233.

${ }^{20}$ Zob. szerzej: K. Zeidler, Zabytek jako szczególny przedmiot obrotu handlowego, „Gdańskie Studia Prawnicze" 21, 2009, s. 387-403. 
ma zastosowanie łączne do ochrony jednych i drugich. Dodać też trzeba - co wynika poniekąd z kompleksowego charakteru gałęzi prawa, jaka jest prawo ochrony dziedzictwa kultury - że większość zasad prawa wyżej wyliczonych to zasady czy to systemowe, czy poszczególnych gałęzi prawa, czy też danych aktów prawodawczych; tylko niektóre z nich - jak przede wszystkim najważniejsza zasada ochrony dziedzictwa kultury - to zasady specyficzne prawa ochrony dziedzictwa kultury. Co więcej, niektóre z tych zasad mają swe źródła w prawie międzynarodowym, a także w tzw. międzynarodowych dokumentach doktrynalnych.

De lege ferenda można rozważać, po pierwsze, które z wyżej przedstawionych zasad winny zostać wprost sformułowane w akcie prawodawczym regulującym problematykę prawa ochrony dziedzictwa kultury; po wtóre, jak należy najpoprawniej sformułować treści przepisu prawnego wyrażającego zasadę prawa; po trzecie, jego właściwe umieszczenie w ramach całej systematyki aktu prawodawczego. Spełnienie tego postulatu będzie prowadziło do wzmocnienia systemu prawnej ochrony dziedzictwa kultury ${ }^{21}$.

dr hab. Kamil Zeidler

Profesor Uniwersytetu Gdańskiego

kamil.zeidler@ug.edu.pl

https://orcid.org/0000-0002-8396-3608

\section{THE PRINCIPLES OF THE LAW ON THE PROTECTION OF CULTURAL HERITAGE - A PROPOSAL FOR A CATALOGUE}

Summary

Among the whole set of legal norms, norms that are legal principles are of particular importance. The attribute that gives a legal norm the status of a principle of law is its importance for the legal system. An important division of legal principles introduces a distinction between the principles formulated directly in the legal text (explicit principles), the principles interpreted from the legal text, although not explicitly expressed in the legal text (implicit principles), and the principles of law not expressed in legislative acts but constituting an element of legal culture (second-degree implicit principles). The law on the protection of cultural heritage is now considered to be a comprehensive branch of law, and one of the basic criteria for separating a branch of law is the possession of own principles of law, a criterion which is satisfied in relation to the catalogue of principles presented in the article, with the guiding principle being the principle of cultural heritage protection interpreted under Articles 5 and 6 of the Constitution of the Republic of Poland. Among other principles of the law on the protection of cultural heritage the following can be distinguished in particular (with the reservation that the catalogue presented in the article has an open character): the principle of access to monuments, the principle of social utility of monuments, the principle of access to information, the principle of control over the state of preservation of monuments, the principle of integrity of the monument, the principle of sustainable development, the principle of cultural heritage management, the principle of change in the usable value of the cultural heritage over time, the principle of financing by the monument holder, the principle of financing from public resources, principles of property protection, the principle of proportionality, the state control over the trading in monuments and the principle of the control of exporting historic objects abroad.

${ }^{21} \mathrm{Na}$ temat systemu prawnej ochrony dziedzictwa kultury zob. K. Zeidler, Prawo ochrony dziedzictwa kultury, Warszawa 2007, passim. 